\title{
Gregorc Öğrenme Stili Sınıflaması ve Öğrenme-Öğretme Durumlarının Gregorc Öğrenme Stillerine Göre Düzenlenmesi
}

\author{
Gregorc Learning Style Delineator and Organizing Learning-Teaching Situations in \\ line with Gregorc Model
}

\author{
Okt. Bülent Alan
}

Başvuru Tarihi: 19.01.2017

Kabul Tarihi: 20.11.2017

\section{Öz}

Eğitimciler ve araştırmacılar uzun yıllardır öğrencilerin nasıl daha iyi öğrenebileceğini araştırmaktadır. Araştırmaların, bireylerin farkl yollardan öğrendiklerini ortaya koymasiyla birlikte kişilik tipleri ve öğrenme stilleri kavramları öne çıkmıştır. Öğrenme stili, bireylerin yeni ve zor bir bilgi ya da problem karşısında onu algilama ve düzenlemede izledikleri nispeten kalıcı davranış örüntüleridir. Öğrenme stili, bir yapı olarak pek çok araştırmacı tarafindan farklı boyutlarina odaklanarak incelenmiştir. Anthony F. Gregorc da öğrenme stilinin bilişsel boyutunu araştırmiş ve Gregorc Öğrenme Stili Envanterini geliştirmiştir. Gergorc modelinde bilişin algılama ve düzenleme boyutu olarak iki kutuplu bir olgu olduğunu ve bireylerin öğrenme stillerinin algilama ve düzenleme yeteneklerine göre farklılaştı̆̆ını belirtmektedir. Bireyler, bilgiyi algılama yeteneklerine göre somuttan soyuta; düzenleme yeteneklerine göre ise ardışıktan dağını̆̆a uzanan bir doğrultuda farklllaşmaktadır. Buna göre, öğrenenler, somut-ardışık ve somut-dağınık ile soyut-ardişık ve soyut-dağınık olmak üzere dört grupta toplanmaktadir. Bu çalş̧mada, Gregorc Öğrenme Stili Envanterinin özellikleri, nasıl hesaplandiğı, dört farklı öğrenme stiline sahip bireylerin genel özellikleri, Gregorc modeline göre yapılan bazı çalışma örnekleri, bunların bulguları ile bu stillere sahip öğrenenlerin en iyi nastl ögrenebilecekleri ve bir uygulama örneği gösterilmiștir.

Anahtar Kelimeler: Öğrenme stilleri, Gregorc Öğrenme Stili Envanteri, Öğrenme-Öğretme Süreci

\begin{abstract}
Educators and researchers have long been studying how learners can learn in better ways. After multiple studies have shown that individuals learn in different ways, personality types and learning style constructs have become prominent. Learning style is the relatively permanent behavioral patterns of learners in perceiving and ordering the new type of information or problem they encounter. The learning style construct has been studied by many researchers focusing on the different aspects of it. Anthony F. Gregorc is one of the researchers focusing on the cognitive dimension of the construct and developed the Learning Style Delineator. Gregorc asserts that cognition is a bi-polar phenomenon consisting of perception and ordering dimensions and individuals differ from each other according to their perception and ordering abilities. Individuals' perception abilities differentiate from concrete to abstract and their ordering abilities vary from sequential to random. As a result, learners' learning styles fall into four different categories as concrete-sequential, concreterandom and abstract-sequential, abstract-random. In this study, the characteristics and calculation of Learning Style Delineator, the common personality traits of the four different learning styles and findings of studies conducted by Gregorc model are explained. The final part of the study discusses how learners who have these four learning styles can learn best and an exemplary application is presented.
\end{abstract}

Keywords: Learning styles, Gregorc Learning Style Delineator, Learning-Teaching Processes

Okt. Bülent Alan, Anadolu Üniversitesi Yabancı Diller Yüksekokulu, balan@anadolu.edu.tr 


\section{Giriş}

Bireylerin nasıl daha iyi öğrenebileceği araştırmacıların sürekli ilgisini çekmiştir. Bu ilgi de araştırmacıları bireylerin farklı kişilik özelliklerini incelemeye yöneltmiştir. Kişilik özellikleri ile ilgili ilk kapsamlı çalışmalar Karl Jung’un geliştirdiği Kişilik Tipleri Teorisi ile başlamış ve öğrenme stillerine uyarlanmıştır (Ekici, 2013, s.213; Güven, 2004, s. 38; Kurt, Ekici, Aktaş, 2014, s. 52). Buna göre bireyler öğrenirken bazı genel eğilimler sergiler ve bu eğilimler bireyin öğrenme stilini yansıtır. Öğrenme stili kavramı bireylerin farklı kişilik özelliklerinin olması sebebiyle öğrenmeyi de farklı yollardan gerçekleştirdiğini temel almaktadır. Gregorc (1984'ten aktaran Miller, 2005, s.288) öğrenme ortamının bireylerin öğrenme stilleri ile uyumlu olduğunda bireylerin daha iyi öğrenebildiğini; ancak bir uyumsuzluk olduğunda öğrenenlerin öğrenmeyi bir engel ya da zor ve hoş olmayan bir etkinlik olarak gördüklerini bulmuştur. Öğrenme stili genel anlamıyla bireylerin yeni bir bilgiyle ya da problemle karşılaştıklarında onu algılar ve işlerken tercih ettikleri ve bilginin türüne ya da zamana göre çok fazla değişmeyen nispeten kalıcı ve bireye özgü davranış örüntüleridir (Güven, 2004, s. 13; Miller, 2005, s.287). Gregorc (Ekici, 2013, s. 214) ise öğrenme stilini bireyin yetenekleriyle ilgili ayırt edici ve gözlenebilir davranışlar olarak tanımlamaktadır.

İlk kez 1960'larda Rita Dunn tarafından ortaya at1lan öğrenme stili kavramı özellikle 1970’lerden sonra yoğun ilgi görmüş ve farklı araştırmacılar tarafından çalışılmıştır (Güven, 2004, s.13). Ancak, öğrenme stili kavramının ve öğrenme-öğretme ortamlarının bireysel farklılıkları dikkate alarak düzenlenmesi gerekliliğinin anlaşılmasına rağmen henüz üzerinde uzlaşılmış tek bir öğrenme stili ölçme aracı bulunmaktadır. $\mathrm{Bu}$ durumun sebebi öğrenme stili kavramının farklı araştırmacılar tarafından çalışılması ve farklı öğrenme stilleri modellerinin ortaya konmasıdır. Bunun bir sonucu olarak da bazı araştırmacılar bireyin öğrenme stilinin bilişsel, bazıları, duyuşsal, bazıları ise fizyolojik boyutuna odaklanmışlardır (Ekici, 2002, s.43). Gregorc’un Öğrenme Stili Sinıflaması ise bireylerin bilgiyi alma, işleme, kodlama ve depolama biçimleri gibi bilişsel boyutuna odaklanan bir modeldir (Ekici, 2002, s.43; Güven, 2004, s.41; Hawk ve Shah, 2007, s.5; Miller, 2005, s.287; Ross ve Shulz, 1999, s.126 Terry, 2002, s.157). Bu yönüyle Gregorc Öğrenme Stili, Kolb’un öğrenme stili modelinde olduğu gibi bilgiyi alma ve işlemede iki kutuplu bir yol izler. Kolb öğrenme stilinde bireyler bilgiyi almada somuttan soyuta, bilgiyi işlemede ise yansıtıcı gözlemden aktif yaşantıya uzanan bir yol izlemektedir. Benzer şekilde Gregorc Öğrenme stilinde de bireyler bilgiyi almada somuttan soyuta ve bilgiyi düzenlemede ise ardışıklıktan dağınıklığa uzanan iki kutuplu bir yol izlemektedir. Kolb’un (1984, s.26) öğrenme stilleri yaşantısal öğrenme modeline dayalı iken Gregorc öğrenme stilleri (Hawk ve Shah, s. 5; Joniak ve Isaksen, s.1044), aşağıdaki bölümde açıklanan arabuluculuk modeline dayanmaktadır.

\section{Gregorc Öğrenme Stili Sınıflandırmasının Kuramsal Temeli}

Gregorc Öğrenme Stili Sınıflaması araştırmacının arabuluculuk (mediation) kuramı adını verdiği kurama dayanmaktadır (Ekici, 2002, s.43; Hawk ve Shah, s.5; Joniak ve Isaksen, 1988, s.1044; Ross ve Shulz, 1999, s.126; Terry, 2002, s.157). Arabuluculuk kuramına göre kişinin beyninde karşılaşttğı bilgiyi algılamasına ve işlemesine yardımcı olan (arabuluculuk yapan) kanallar vardır. Gregorc’a göre kişinin arabuluculuk yetenekleri sahip olduğu bu arabuluculuk kanallarını kullanabilme kapasitesini açıklamaktadır (Ross ve Shulz, 1999, s.126). Bireyler sahip oldukları arabuluculuk kanalları ve yeteneklerinin kapasitelerine göre birbirinden ayrılmakta ve farkl1 ortamlarda farklı öğrenme özellikleri göstermektedirler. Gregorc’a göre öğrenme stili bireyin (bilgiyi almadaki) arabuluculuk yetenekleri hakkında ipucu veren gözlenebilir ve ayırt edici özelliklerinden oluşmaktadır (Ekici, 2002, s.42; Güven, 2004, s.41; Terry, 2002, s.157).

Gregorc'un öğrenme stili sınıflaması özellikle yetişkinlerin iki temel arabuluculuk yeteneğine odaklanmaktadır; algllama ve düzenleme. Algılama bireyin bilgiyi kavrama yeteneği iken düzenleme bireyin karşllaştığı bilgiyi kendine göre anlamlaştırarak zihninde sistemleştirmesi ve depolamasıdır. Bireylerin bilgiyi algılama ve düzenleme yetenekleri onların öğrenme stillerini tanımlamaktadır. Gregorc algılama ve düzenleme kavramları üzerinde uzun yıllar çalıştıktan sonra bilişin iki kutuplu bir olgu olduğuna karar vermiştir. Bilişin iki kutuplu olmasının sebebi ise bilgiyi algilama, düzenleme, işleme ve anlamlandırmanın da ayrı iki boyutunun olmasından kaynaklanmaktadır. Diğer bir ifadeyle, algılama ve düzenleme yeteneklerinin iki ayrı alt boyutu bulunmaktadır (Terry, 
2002, s.157). Gregorc'un öğrenme stili sinıflamasında bireyler algılama yeteneklerine göre soyuttan somuta ve düzenleme yeteneklerine göre de $\operatorname{ard} \imath$ şılıktan dağınıklı̆a doğru uzanan bir doğrultuda farklılık göstermektedirler.

Soyut kavramıyla bireyin duyular, hisler ve inançlar yoluyla gözle görünmeyeni algılayabilme kapasitesi açılanmaktadır. Soyut öğrenme stiline sahip bireyler verileri zihinlerinde canlandırıp kavramaktadırlar. Tamamıla soyut stildeki bireyler birer idealisttirler. Somut öğrenme stiline sahip bireyler ise veriyi anlamak ve zihinlerine kaydetmek için beş duyularını kullanırlar. Tamamıyla somut öğrenme stilinde olan bireyler gerçek birer realisttirler. Ardışık öğrenmeyi tercih eden bireyler verileri doğrusal ve sistemli bir biçimde aşama aşama algılarlar ve düzenlerler, kendilerini kesin tanımlamalarla ifade ederler. Dağınık düzenleme yeteneğine sahip bireyler ise yeni bir bilgi karşısında zihinlerini doğrusal olmayan ve çok boyutlu bir biçimde düzenlerler. Verilerin herhangi bir sıralamada sunulmasına ya da düzenlenmesine ihtiyaç duymazlar. Bu özellikleri ile birçok farklı veriyi aynı anda işleyebilme yetenekleri vardır. Dağınık öğrenme stiline çok güçlü olarak sahip bireyler her zaman önce büyük resmi görüp ondan sonra detaylara yönelirler (Ekici, 2002, s.44; Ross ve Shulz, 1999, s.128 Terry, 2002, s.159).

Gregorc'un öğrenme stili sinıflaması soyut-somut ve ardışık-dağınık yeteneklerinin doğrusal bir düzlemde kesişmesinden meydana geldiği savına dayanmaktadır. Bireyin bu doğrulardan birine doğru olan eğilimlerinin bileşimleri o bireyin öğrenme stilini göstermektedir. Bu eğilimler doğuştan gelen özellikler olsa da Gregorc bireylerin doğuştan gelen stillerinin dişındaki stillerde de işlem yapabilme becerisine sahip olmaları gerektiğini belirtmektedir (Cassidy, 2004, s.429). Gregorc, bu bileşimleri ya da öğrenme stillerini somut-ardışık, soyut ardışık, somut-dağınık, soyut-dağınık olmak üzere dört grupta toplamıştır (Cassidy, 2004, s.429; Ekici, 2002, s.43; Güven, 2004, s.41; Hawk ve Shah, s.5, 2007; Kurt, Ekici, Aktaş, 2014, s.51; Miller, 2005, s.289; Ross ve Shulz, 1999, ss.127-129; Terry, 2002, ss.57-158). Duruma göre bazen bireyler tüm öğrenme kanallarını kullanarak işlem yapabilme yeteneğine sahip olsa da genellikle bu dört bileşenin birine daha fazla yönelme eğilimi göstermektedirler (Miller, 2005, s.289).

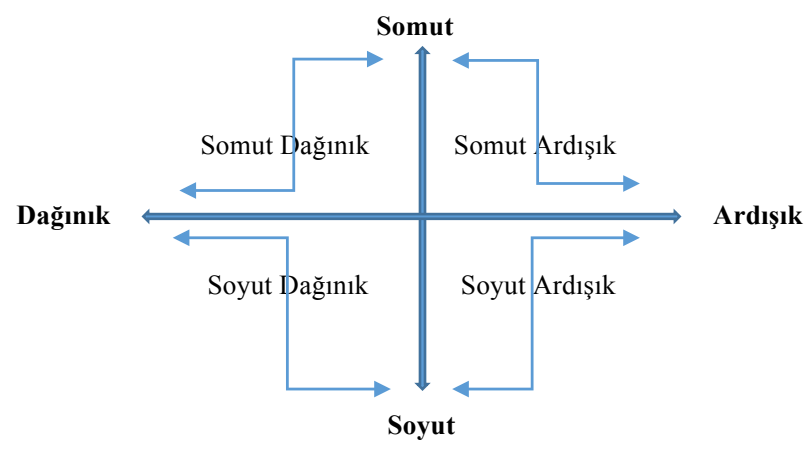

Şekil 1. Gregorc Öğrenme Stilleri

\section{Somut Ardışık}

$\mathrm{Bu}$ tip öğrenenlerin en belirgin özellikleri yaparak öğrenmeye olan eğilimleridir. Beş duyu organlarını kullanmakta yeteneklidirler. Parçalardan çok bütüne odaklanırlar. Birbirini takip eden aşamalı görevler yapmayı severler. Bu sebeple yönergeleri çok dikkatli takip ederler. Bilginin kendilerine basitten karmaşığa doğru sunulmasını tercih ederler. Mükemmel düzenleme yetenekleri vardır (Terry, 2002, s.160). Öğrenme ortamları yapılandırıldığında ya da öğretmenler tarafından yönlendirildiklerinde daha iyi öğrenirler. Bireysel çalışmayı grup çalışmalarına tercih ederler. Hayal güçlerini kullanmaktan çok mantıklarına güvenirler. Soyut kavramlarla ilgilenmezler. Sonu ol- 
mayan sınıf içi tartışmalardan hoşlanmazlar ve kesin cevabı olmayan açık uçlu soruları cevaplamada zorlanabilirler. Güven (2004, s.42) somut ardışık öğrenme stilindeki bireylerin genel öğrenme özelliklerini şöyle sıralamaktadır:

- Mantıksal bir aşamalılık izleme

- Duyularını yüksek düzeyde kullanma

- Kişiselleştirilmiş bilgiyi kullanma

- Gerçekçi ve sabırlı olma

- Kendi deneyimlerine güvenme

- Sessiz ve durağan olma

\section{Soyut Ardışık}

Bu stile sahip bireyler mantıklı karar alma becerisine sahiptirler. Amaca dönüktürler ve bilimsel çalışmalara yatkındırlar. Fikirlerinin duyulup takdir edilmesinden hoşlanırlar. Hırslı ve istekli okuyuculardır. $\mathrm{Bu}$ sebeple kelime hazineleri çok geniştir. Öğrenmek onlar için bir tutkudur ve bilgiyi güç olarak kabul ederler (Ross ve Shulz, 1999, s.128). Yalnız ve sessiz ortamlarda çalışmayı severler. Öğretmenlerinin tam bir konu uzmanı olmasını beklerler. Eleştirel yazılar yazmaya daha yatkındırlar fakat eleştiriye açık değildirler. Bu bireyler şifre çözme konusunda oldukça yeteneklidirler. Kavramlarla uğraşmayı çok severler. Öğrenmeye başlamadan önce zihinlerinde boş bir kavram dosyası açarlar ya da boş bir resim çerçevesi oluştururlar. Yeni öğrendikleri bilgileri ihtiyaçları doğrultusunda belli bir düzen içerisinde bu boş resim çerçevesinin içine yerleştirirler ve konuyla ilgili bir bütüne ulaşmaya çalişırlar. Bu sebeple sentezleme yetenekleri gelişmiştir (Ekici, 2002, s.44; Güven, 2004, s.42). Soyut ardışık bireyler grup çalışmalarını sevmezler. (Terry, 2002, s.160). Bu yüzden farklı fikirlere sahip bireylerle bir araya gelmekten hoşlanmazlar. Kısıtlı zaman süresinde çalışmak onları zorlar. Bu stile sahip bireylerin genel özelliklerini şöyledir:

- Akıl yürütme becerisine sahip olma

- Aşamalı düşünme yeteneğine sahip olma

- Mantıksal ve analitik düşünme ve sentez yapabilme yeteneğine sahip olma

- Öğrenmede kavramsal pencereleri kullanma

- Kavramları ve düşünceleri gruplama

\section{Somut Dağınık}

Bu öğrenme stiline sahip bireyler problem çözme konusunda yeteneklidirler (Ekici, 2003, s.50). Bağımsız ve yaratıcı kimselerdir ve bu yüzden hayal güçleri çok gelişmiştir. Sürekli yeni fikirler üretmenin telaşındadırlar. Öğretmenlerinin ya da diğer arkadaşlarının yönlendirmelerini sevmezler. Doğal liderlik özellikleri taşırlar (Terry, 2002, s.160). Somut dağınık öğrenme stiline sahip bireyler araştırarak öğrenmeyi çok severler. Risk almaktan çekinmezler. Genellikle deneme yanılma yoluna başvururlar ve sezgilerine güvenerek keşfetme eğilimindedirler (Terry, 2002, s.160). Bu yüzden yapılandırılmış görevlerden ve k1sitlamalardan hoşlanmazlar. Bu özellikleri onlara bilgiyi sistematik biçimde ya da düzen içinde verilmese de algilama ve düzenleme yeteneği sağlar. Ancak verilen görevleri zamanında tamamlamada, öncelikleri belirlemede ve hızlıca sonuca ulaşmada zorlanırlar. $\mathrm{Bu}$ stildeki öğrencilerin genel özellikleri şöyledir (Güven, 2004, ss.42-43):

- Deneyime dayalı öğrenme

- Hata yapmaya yatkınlık

- Sezgi gücüyle bilgiye ulaşma

- Yaparak öğrenme

- Öğrenmede bağımsız olma

- Üç boyutlu düşünme gücü

- Değişime açık olma

\section{Soyut Dağınık}

Bu öğrenme stilindeki öğrenciler bilgiyi belli bir düzen içerisinde öğrenme ihtiyacı duymazlar. Bu özellikleri sebebiyle çoklu duyumsal ortamlarda daha iyi öğrenebilmektedirler. Kurallardan ve kisttlamalardan hoşlanmazlar. Algıları etraflarında gerçekleşen olaylara ve uyarıcılara sürekli açıktır ve aynı anda birden fazla göreve odaklanabilirler. Aynı zamanda oldukça sosyal bireylerdir. Takım çalışmasından ve uzun grup tartışmalarından hoşlanırlar. Oldukça meraklı bir yapıları vardır ve farklı seçenekleri denemeyi severler. Yazma becerileri ve dolayısıyla sanatsal anlatım yetenekleri gelişmiştir. Bu stile sahip bireylerin genel özellikleri aşağıdaki gibidir (Güven, 2004, s.43; Terry, 2002, 160): 
- Duygulara yoğunlaşma

- İlişkilere yoğunlaşma

- Hayalci olma

- Etkin olma

- Öğrenme deneyimlerini genel olarak değerlendirme

\section{Gregorc Öğrenme Stili Ölçeği}

Gregorc'un öğrenme stili ölçeği de aynı Kolb’un öğrenme stili ölçeğinde olduğu gibi bir döngü içerisinde gösterilmekte ve bireyin öğrenme stili bu döngünün içerisinde bulunduğu konuma göre belirlenmektedir. Gregorc Öğrenme Stili Sınıflaması, bireylerin bilişsel ögrenme stillerinin belirlenmesinde bireylerin kendilerini isimler ve sıfatlar kullanarak tanımlamalarını gerektiren bir kelime matrisi kullanmaktadır. Matris iki ayrı setten oluşmakta ve her bir sette dörder seçeneğin olduğu beş madde bulunmaktadır. Dolayısiyla matriste toplam 40 madde/soru bulunmaktadır. Sorulardaki dört seçeneğin her biri somut-ardışık, soyut-ardışık, somut-dağınık ve soyut-dağınık olmak üzere ayrı bir öğrenme seçeneğine karşılık gelmektedir. Bireyler matrisi yanıtlarken kendi kişisel özelliklerini düşünerek her bir seçenekten kendilerini en iyi tanımlayan seçeneği 4 en yüksek ve 1 en düşük olmak üzere sıralamaktadırlar. Bireyler iki ayrı setten aldıkları puanları topladıklarında iki ayrı öğrenme boyutuna karşılık gelen puanlarını hesaplamış olmaktadırlar. Bu puanlar bir araya getirildiğinde ise dört öğrenme stiline karşıllık gelen kümülatif puanlar hesaplanmaktadır. Bireyin en yüksek çıkan puanı onun tercih ettiği bilişsel öğrenme stilini ortaya çıkarmaktadır (Terry, 2002, ss.157-159).

Gregorc, 27 ve daha üstündeki bir puanın bireyin o öğrenme stilindeki özelliklerinin \% 60'nı açıkladığını ifade etmektedir. Ölçeğe göre çok az kimsenin skoru 15 ve altında çıkmaktadır. Bu sebeple 27 ve 40 arasında bir skor güçlü bir öğrenme stilini gösterirken, 16 ve 26 arasındaki bir skor orta derecede güçlü bir öğrenme stilini, 10 ve 15 arası bir skor da zayıf bir öğrenme stilini göstermektedir. Matrisin yapısı gereği bireyler 10 'dan düşük ve 40 'tan yüksek bir skor elde edemezler (Ekici, 2002, s.45; Terry, 2002, ss. 158159). Ekici (2002, ss.44-45) bireyin öğrenme stilinin hesaplanmasını kendisine sunulan soruları "Ben kimim?" sorusunu düşünerek cevaplaması gerektiğini belirtmektedir. Ekici, puan hesaplamasını şu şekilde açıklamaktadır: Ölçekteki 10 soruda da aynı seçenek işaretlendiğinde, o öğrenme stilinde alınabilecek en yüksek puan 40 'tır. Bir başka ifadeyle bireyin dört öğrenme seçeneğinden alabileceği puanlar 10 ila 40

\section{SOMUT-ARDIŞIK}

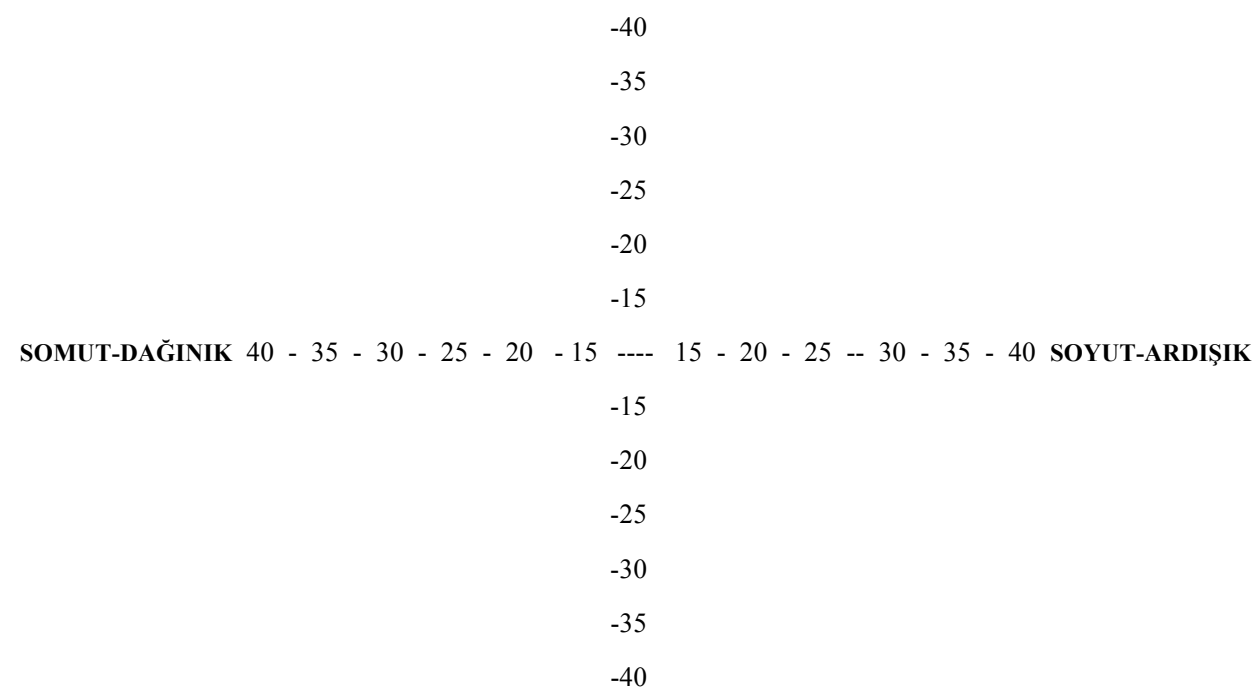

SOYUT-ARDIŞIK

Kaynak: Ekici; 2002, s. 45

Şekil 2. Gregorc Öğrenme Stili Sınıflaması 
arasında değişmektedir. A seçeneğinden alınan puanlar; Somut-Ardışık, B seçeneğinden alınan puanlar Soyut-Ardışık; C seçeneğinden alınan puanlar Somut-Dağınık ve D seçeneğinden alınan puanlar Soyut-Dağınık öğrenme stilindeki puanları ifade etmektedir. Bireyin tüm seçenekleri işaretlemesi sonucunda, kısaca her bir maddedeki seçenekleri kendine göre önem sırasına koyması sonucu alabileceği puanların toplamının 100 olması gerekmektedir.

Gregorc'un öğrenme stili ölçeğinin öntest-sontest korelasyon katsayısı .85 ve .88 arasında değişmektedir (Gregorc 1982b'den aktaran Miller, 2005, s.289). Ölçeğin güvenirlik katsayıları ise Somut-Ardışı öğrenme stili için .78, Somut-Dağınık öğrenme stili için .87, Soyut-Ardışık öğrenme stili için .89 ve Soyut-Dağınık öğrenme stili için 93 çıkmıştır (Ekici, 2002). Ancak Joniak ve Isaksen (1988, s.1046-1047) Gregorc Öğrenme Stili Ölçeği’nin güvenirlik katsay1larını ölçtükleri çalışmalarında daha düşük değerler bulmuşlardır. Somut-Ardışık ve Somut-Dağınık ikilisi ile Soyut-Ardışık ve Soyut-Dağınık ikilisinin katsayıları istatistiksel olarak ( $\mathrm{p} \leq .001)$ anlamlı çıkmış ve .53 ile .64 arasında değişmiştir. Analizler Ölçeğin Ardışık-Dağınık boyutunun Somut-Ardışığı SoyutDağınıktan, Soyut-Ardıșı̆̆ı da Soyut-Dağınıktan ayrıştırdığını göstermiştir. Fakat Somut-Dağınık ve Soyut-Dağınık ikilileri istatiksel olarak anlamlı bulunmamıştır. Somut-Ardışık ve Soyut-Ardışık ikilileri anlamlı iken değerleri yalnızca .29 ve .28 çıkmıştır $(\mathrm{p} \leq .001)$. Ölçeğin Somut-Soyut boyutunun ne Somut-Dağınığı Soyut-Dağınıktan ne de Somut-Ardış1ğ 1 Soyut-Ardışıktan ayırabildiği bulunmuştur. Ayrıca bu korelasyonlar ölçekte yalnızca Soyut-Ardışık ve Somut-Dağınığın birbirleriyle ilişkili olmadığını ortaya çıkarmıştır. Joniak ve Isaksen (1988, s.1047) ölçeğin dört öğrenme stilini de ölçmeyi amaçlamasından dolayı ölçekteki dört alt boyutun da birbirinden bağımsız olması gerektiğini belirtmektedirler. Ölçeğin Türkçe’ye uyarlanması çalışması ise Ekici (2002, s. 46) tarafından yapılmıştır. Ekici’nin çalışmasının güvenirlik katsayıları Gregorc'un orijinal güvenirlik katsayılarına yakın çıkmıştır ve Ekici, Türkçe’ye çevirdiği ölçeğin Türk kültürü örneklemi üzerinde de kullanabileceğini ifade etmektedir.

Gregorc Öğrenme Sinıflaması kullanılarak yapılan pek çok çalışma bulunmaktadır. Moore (1990, s.35) beste yapmak ve öğrenme stilleri arasında bir ilişkinin olup olmadığını araştırmıştır. Çalışmasının so- nucunda sezgisel müzik yeteneği ve soyut-dağınık öğrenme stili arasında güçlü bir ilişki bulmuştur. Davidson, Savenye ve Orr (1992, s.348) öğrenme stillerinin bilgisayar kavramları ve uygulama becerileri üzerinde bir etkisinin olup olmadığını incelemişlerdir. Araştırmanın bulguları çok farklı öğrenme ve ölçme aracı kullanılmış olmasına rağmen eğitimde bilgisayar teknolojileri kullanımında Soyut-Ardışık öğrenme stilindeki öğrencilerin Soyut-Dağınık öğrencilere göre çok daha başarılı olduğunu ortaya koymuştur. Ross, Drysdale ve Shulz (2001a, s.409) ise çok daha kapsamlı ve uzun süreli bir araştırma yapmıştır. Araştırmacılar bilişsel öğrenme stilinin üniversite düzeyinde iki ayrı bilgisayar uygulamaları dersindeki akademik başarı üzerinde etkisini ölçmüşlerdir. Dört yıl süren ve 800'den fazla öğrencinin katıldığ 1 bu çalışmanın sonunda araştırmacılar öğrenme stilinin her iki ders için de akademik başarı üzerinde anlamlı etkisi olduğunu bulmuşlardır. Bulgular ardışık öğrenme stilindeki öğrencilerin dağınık öğrenme stilindeki öğrencilere göre daha başarılı olduğunu göstermiştir. Ross Drysdale, ve Shulz (2001b, s.285) araştırmalarının bir başka boyutunda üniversite birinci sınıf öğrencilerinin akademik başarısını 19 farklı üniversite dersinde incelemiştir. 1993-1997 yılları arasında 4 yıl süren araştırmaya 4546 üniversite öğrencisi katılmıştır. Araştırma sonucunda öğrenme stilinin 19 dersten 11'inde anlamlı düzeyde etkili olduğu bulunmuştur. Araştırmacılar fen bilimleri ve matematikle ilgili alanlarda ardışı öğrenme stiline sahip öğrencilerin daha başarılı olduğunu, güzel sanatlarla ilgili derslerde ise dağınık öğrenme stilindeki öğrencilerin daha başarılı olduğunu bulmuşlardır. Temel ve sosyal bilimler alanlarında ise tüm öğrenme stilindeki öğrencelerin eşit performans sergiledikleri gözlenmiştir.

Türkiyede Ekici (2013, s.221) öğretmen adaylarının öğrenme stilleri ile cinsiyetleri arasında anlamlı bir fark bulmuştur. Öğrencilerin öğrenme stilleri ile akademik başarıları arasında ise anlamlı bir fark çıkmamıştır. Kurt, Ekici ve Aktaş (2014, s.56) biyoloji öğretmen adaylarının öğrenme stilleri ile kişilik tipleri arasındaki ilişkiyi inceledikleri çalışmalarında Gregorc’un Öğrenme Stili Ölçeğinin yanında Keirsy Temperament Sorter II kişilik tipleri ölçeğini kullanmışlardır. 119 biyoloji öğretmen adayının katıldığı çalışmada öğretmen adaylarının öğrenme stilleri ile kişilik tipleri arasında pozitif ve orta düzeyde ilişkiler bulunmuştur. En yüksek ilişki Somut-Ardışık öğrenme stili ile Koruyucu kişilik tipi arasında bulunmuştur. 


\section{Gregorc Öğrenme Stili Ölçeğine Göre Eğitim Durumlarının Düzenlenmesi}

Öğretmenlerle öğrencilerin öğrenme stilleri arasında bir uyum olması öğrenenlerin tercih edecekleri bir durumdur. Öğretmenlerin öğretme stratejileri öğrencilerinin öğrenme stilleri ile uyuşmasa bile öğretmenlerin tüm öğrencilere hitap edebilmesi ve faydalı olabilmesi için farklı stratejiler ve yöntemler kullanması gerekmektedir. Buna paralel olarak da öğrencilerin farklı ögrrenme etkinliklerini deneyimlemeleri ve öğretmenlerin bu konuda öğrencilerini cesaretlendirmeleri faydalı olacaktır. Ancak öğretmenlerin bir grup öğrenciyi memnun etmeye çalışırken diğer bir grubun da derste sıkılmasını ya da kaygılanmasını önleyecek dengeyi kurması gerekmektedir (Terry, 2002, s.162). Terry'nin, Gregorc Öğrenme Stili Sınıflamasına göre belirlenmiş bir öğrenci grubuna eğitim verirken öğretmenin nelere dikkat edebileceğine ilişkin önerileri ve dört farklı öğrenme stiline sahip bireylerin genel öğrenmeleri için açıkladığı özellikler aşağıda özetlenmiştir (ss.163-171).

\section{Somut-Ardışık}

$\mathrm{Bu}$ öğrenciler öğretmen merkezli derslerden hoşlanırlar. Derste öğrencilerin sunu yapması gereken durumlarda bile sunularının yapilandırılmalarını ve öğretmenlerinin yönlendirmelerini tercih etmektedirler. Her türlü soyut kavramın en ince detayına kadar anlatılıp örneklendirilmesini isterler. Somut-Ardışık öğrenme stilindeki öğrenciler saha gezilerini ve etkin katılımlı dersleri sözel anlatımlara tercih ederler. Gözlem yapmak yerine bizzat kendileri deneyerek öğrenmek isterler.

Somut-Ardışık öğrenciler hareketli sınıf ortamlarını sevseler de gürültüden hoşlanmazlar. Bu yüzden s1nıf içi tartışmaların amaçli, düzenli ve nispeten gürültüsüz gerçekleşmesini isterler. Yapılandırmaya ve düzenlemeye olan eğilimleri onları iyi birer proje ve takım çalışanı yapar. Grubun işe devam edebilmesini ve görevini adım adım yürütebilmesini sağlar. Görevin ya da projenin öğretmenin yönergelerine göre yapılmasına dikkat ederler.

Somut-Ardışık bireyler tek başlarına da iyi çalışıp organize olurlar. Detaylara yoğunlaşmada yeteneklidirler. Laboratuvar çalışmaları, alıştırma kitapları ve bilgisayar destekli öğretim gibi yaparak öğrenme ortamlarını tercih ederler. Görevlerini zamanında yaparlar. Kendilerine verilen görevin adım adım ve açıkça anlatılmasını ve açıklanmasını isterler. Bu se- beple açık uçlu sorulardan ya da net ifade edilmeyen ödevlerden veya çalışma konusunu kendilerinin belirlemesinden hoşlanmazlar.

Somut-Ardışık öğrenciler sınavlarda kendilerinden somut cevapların istendiği ve hafızaya ve hatırlamaya dayalı detay sorulardan hoşlanırlar. Bu yüzden nesnel doğru-yanliş, derecelendirme, çoktan seçmeli soru tipleri ile soruyu tek bir şekilde geliştirmeleri beklenen uzun cevaplı soruları yanitlamayı severler. Aynı zamanda her sorunun kaç puana karşılık geldiğini kesin olarak bilmek isterler. Bu öğrenciler sessiz ve rahatsız edilmedikleri sınav ortamlarında daha başarilı olurlar.

\section{Soyut-Ardışık}

$\mathrm{Bu}$ öğrenme stilindeki öğrenciler de Somut-Ardışık stilindeki öğrenciler gibi öğretmenin fikirleri mantıki bir sırada anlattığ 1 uzun dersleri severler. Öğretmenin düşünce zincirini takip ederken konuya ilişkin kendi ilgilerini ve fikirlerini oluştururlar. Bu öğrenme stilindeki öğrencilerin bilgiye açlığı ancak öğretmenlerin uzmanlıklarını yansitacakları kapsamlı ve detaylı anlatımlarla doyurulabilir.

Soyut-Ardışı stildeki öğrenciler kendi arkadaşları yerine öğretmenleri ile entelektüel tartışmalara girmeyi tercih ederler ve grup çalışmalarından kaç1nırlar. Ancak grup çalışmalarını sevmeseler de çalıştıkları gruba sahip oldukları araştırma becerileri ile katkı yapmaktadırlar. Sınıf içi tartışmaların da belli bir düzen içerisinde ve analitik düşünme oturumları şeklinde yapılmasını isterler. Genellikle entelektüel tartışmaları yapabilmelerine imkân tanıyan geniş kelime hazineleri vardır. Eleştirel analize odaklanmaları ise diğer arkadaşlarının onları fazla eleştirel bulmalarına sebep olmaktadır.

Soyut-Ardışık stildeki öğrenciler okumaya dayalı bireysel çalışmaları, bilgisayar destekli öğretimi, laboratuvar deneylerini çok severler. Yazılı materyalleri okumayı ve çalışmayı hemen bitiren azimli okuyuculardır. Yazılı rapor sunacakları ve kütüphane araştırmaları yapmalarını gerektiren çalışmaları tercih ederler. Bu tercihleri analitik düşünebilme ve sentez yapabilme yeteneklerinden kaynaklanmaktadır. Bu öğrenciler sınıflarının düşünenleridir. Ancak yazılı ödevlerin yerini alan model ve poster gibi yaparak öğrenmeyi gerektiren çalışmaları sevmezler. Öğrenmeyi öğrenme aşkı için sevmeyen öğrencilerle anlaşamazlar. 
Soyut-Ardışı öğrenme stilindeki öğrenciler de Somut-Ardışık öğrenciler gibi detaylı cevapları olan sınav sorularını severler. Analitik yapıları sayesinde bilgiyi çözümlemelerine imkan tanıyan uzun sınav sorularını tercih ederler. Kendi belirledikleri standartlarını karşılamak için zamana ihtiyaçları vardır. $\mathrm{Bu}$ sebeple evde cevaplanan sinavlardan hoşlanırlar. Mantıksal analizler yapabilmeye olan yatkınlıkları sebebiyle ayrıntılı yönergelere ihtiyaç duymazlar. Bunun yerine kendi sınav stratejilerini geliştirmeyi yeğlerler. Sesiz ve rahatsız edilmedikleri sınav ortamlarını tercih ederler.

\section{Somut-Dağınık}

$\mathrm{Bu}$ öğrenme stilindeki öğrenciler bilgiyi öğretmenin aktarmasından ziyade deneme yanilma yoluyla cevab1 kendileri bulmak ister. Bir konunun ana fikrini hemen yakalayabilirler. Bu yüzden öğretmenlerin uzun ve detaylı anlatımlarından çabuk sıkılırlar. Bir an önce sonuca ulaşma arzuları onları öğretmenlerinin anlatımlarını kesmeye ya da dersin konusunu başka bir yöne çekmeye yöneltir.

Somut-Dağınık öğrenme stilindeki öğrenciler grup tartışmaları ve proje çalışmalarında başarı göstermektedir. Diğer öğrenciler ile etkileşime geçmek onlardaki rekabetçi, özgürlükçü ve ilham verici bir çevre ihtiyaçlarını karşılamaktadır. Somut-Dağınık öğrenciler özellikle sinıf içi oyunlara ve simülasyonlara katılmayı çok severler. Grup tartışmalarında başı çekerler ve genellikle daha önce kimsenin aklına gelmeyen fikirler üretirler ve önerilerde bulunurlar. Proje çalışmalarında da diğer arkadaşlarının görev dağılımını yaparak ve onları farklı çözüm önerileri getirmeye cesaretlendirerek iyi birer liderlik üstlenirler. Ancak bazen fevri hareket etme ve kolay risk alma eğilimleri yüzünden grubu çok farklı yönlere çekebilir ve görevin tamamlanmasını tehlikeye sokabilirler.

Somut-Dağınık öğrenciler deneysel, bağımsız ve yaratıc bireylerdir. Yaratıcı sezgilerine ket vurmayan otonom ortamlardan hoşlanırlar. Bu yüzden keşfetmeye yönelik ortamlarda başarılı olurlar. Öz rekabetçi yapıları sebebiyle kendileri için yüksek standartlar belirlerler ve öğrenme çıktılarını değerlendirirken bu standartlara dayanırlar. İçüdüsel akıl yürütebilme ve bilgiyi üç boyutlu işleyebilme becerileri güçlü özelliklerindendir. Yeterli bilgiye sahip olmadan hemen bir kanıya veya sonuca ulaşmaları ve görevleri yarım bırakmaları ise zayıf yönleridir.
Somut-Dağınık öğrenciler sezgisel, yaratıcı ve bağımsız düşünme becerilerini sınav ortamlarına taşırlar. $\mathrm{Bu}$ özellikleri onları açı uçlu ve problem çözmeye dayalı soruları tercih etmeye yönlendirir. Bu öğrenme stilindeki öğrenciler bir sonuca ulaşmak zorunda oldukları, varsayımda bulunmaları ve kendi fikirlerini açılamaları gereken sorularda oldukça başarılı olurlar. Ancak derin bir düşünceye daldıklarında zamanı iyi takip edemeyebilirler ve sınav zamanını iyi ayarlayamayabilirler. Bu sebeple, sınıf içi sınavlar rekabetçi yapılarına uygun olsa da daha çok ev ödevi şeklinde verilen ve ürün odaklı projeler üzerinden değerlendirilmeyi tercih ederler. Sınav yapılan ortamın özellikleri bu gruptaki öğrenciler için bir sorun değildir çünkü sınırlandırılmamış ortamlarda da kolaylıkla konsantre olabilirler.

\section{Soyut-Dağınık}

Soyut-dağınık öğrenme stilindeki öğrenciler öğretmenlerin yönlendirdiği tartışmaları sıkıcı ve boğucu bulmaktadır çünkü yapılandırılmış öğrenme ortamlarını sevmezler. Eğer öğretmen anlatımına dayalı bir dersi dinlemeleri gerekiyorsa bu dersin kısa sürmesini ve ders sonunda bir soru-cevap bölümünün olmasinı tercih ederler. Televizyon programları ya da filmler hakkındaki sınıf içi tartışmalardan hoşlanırlar. Soyut-Dağınık öğrenme stiline sahip bireylerin ortamı verilen mesajla ilişkilendirmelerinden dolayı öğretmenin sınıftaki kişiliği ve tutumu verilen mesajlar kadar önemlidir.

Soyut-dağınık öğrenme stilindeki öğrencilerin dağınık stile yakın bireyleri grup tartışmalarını ve proje çalışmalarını severler. En çok da soru-cevap oturumları biçimindeki genel tartışmaları tercih ederler. Genellikle çabuk kavrayan, eleştirel ve diğerleri ile iyi ilişkiler kurma çabasındaki bireylerdir. Sınıf ortamına duygudaşlık, hayal gücü ve vicdan gibi değerleri taşırlar. Proje çalışmalarında ilginin merkezi olurlar. Grup bütünlügüne ve uyumuna katkı getirirler. Ancak görevlerini zamanında yapmakta zorlanmaktadırlar.

Soyut-Dağınık öğrenme stiline sahip bireyler ikili ya da küçük grup çalışmalarını tercih etseler de bağımsız çalışacakları proje çalışmalarını da severler. Bu öğrenciler okuyacakları kaynakları, konuları ve ödev türünü kendilerinin seçmesine imkan tanıyan özgür ortamları tercih ederler. Aşırı yapılandırılmış ödevlerden hoşlanmazlar. Yapılandırılmamış ortamlarda problem çözmede ve soyut öğrenmeye dayalı etkin- 
liklerde başarılı olurlar. Bu yüzden bilgisayar destekli derslerde ve öğretimde ve aynı zamanda ödevlerin yükümlülüklerini yerine getirmek ve son tarihlerine dikkat etmek gibi detaylara yoğunlaşmada zorluk yaşamaktadırlar.

Soyut-Dağınık öğrenme stiline sahip öğrenciler yalnız çalışmayı sevmedikleri ve detayları çalışmada ve hatırlamada zorlandıkları için sınav ortamlarını stresli bulmaktadırlar. Sınavlarda nesnel doğru-yanlış, çok$\tan$ seçmeli, ya da uzun makale tarzındaki sorular yerine kısa cevaplı makale sorularını tercih ederler.
Yorum gerektiren sorularda sentez ya da analiz gerektiren sorulara göre daha başarılı olurlar. Sanatsal ifade güçlerini yansıtmalarını sağlayan sınıf sunumlar1 veya sözlü anlatıma dayalı sınavları tercih ederler. Etkileşimli öğrenme ihtiyaçlarına hitap edecek daha az yapılandırılmış sınav ortamlarını tercih etseler de başkalarından rahatsız olmamak için daha fazla sınırlandırılmış sınav koşullarına ihtiyaç duyabilirler.

Hawk ve Shah (2007, s.6) ise Gregorc öğrenme stilindeki bireylere en uygun etkinlikleri Tablo 1'de aşağ ${ }^{-}$ daki gibi sıralamıştır:

Tablo 1. Gregorc Öğrenme Stillerine Uygun Etkinlikler

\begin{tabular}{|l|l|l|l|}
\hline Somut-Ardışı & Soyut-Ardışı & Soyut-Dağınık & Somut-Dağını \\
\hline Kontrol listeleri & Konferans Tipi Ders & Haritalama & Beyin Fırtınası \\
Çalışma yaprakları & Taslaklar & Grup Çalışması & Olanaklar Yaratma \\
Grafikler & Belgeleme & Karikatürler & Durum Çalı̧maları \\
Haritalar & Uzun Okumalar & Müzik & Yaparak Öğrenme \\
Gösterimler & Dinleme kaydı & Mizah & Haritalama \\
Saha Gezileri & Yazılı Raporlar & Tartışma & Seçenekli Okuma \\
Diyagramlar & Araştırma Yapma & Rol Oynama & Simulasyonlar \\
Akış Şeması & Dönem Ödevleri & Görüşme Yapma & İnceleme \\
& Bilgisayar Destekli & Günlük Yazma & Problem Çözme \\
& Öğretim & & \\
\hline
\end{tabular}

Kaynak: Butler 1986'dan aktaran Hawk ve Shah, 2007, s. 6

Tablo 2. Gregorc Öğrenme Stillerine Göre Web Uygulamaları

\begin{tabular}{|c|c|}
\hline Öğrenme Stili & Genel Web Uygulamaları \\
\hline Somut-Ardışık & $\begin{array}{l}\text { Yönergeli çevrimiçi sanal laboratuvarlar } \\
\text { Problemlerin ayrıntılı çözümlerinin gönderilmesi } \\
\text { Ders materyallerinin Powerpoint yansıları } \\
\text { Ders zorunlulukları (örneğin ödevlerin detaylı yönergeleri ) }\end{array}$ \\
\hline Somut-Dağınık & $\begin{array}{l}\text { Video örnek olayları } \\
\text { Çevrimiçi kaynak linkleri olan bağımsız çalışma fikirleri } \\
\text { Öğrencilerin önceki çalışmalarının linkleri }\end{array}$ \\
\hline Soyut-Ardışık & $\begin{array}{l}\text { İleri çalışmalar ya da karmaşık öğrenmeler için kaynak linkleri } \\
\text { Çevrimiçi ders sözlükleri } \\
\text { Ders notlarının ve çevrimiçi kaynakların bir araya getirileceği çevrimiçi } \\
\text { defter }\end{array}$ \\
\hline Soyut-Dağınık & $\begin{array}{l}\text { Tartışma odaları } \\
\text { Sohbet Odaları } \\
\text { Haber grupları ya da duyuru panosu sistemleri } \\
\text { Ders e-posta yönetim sistemi }\end{array}$ \\
\hline
\end{tabular}

Kaynak: Ross ve Shulz, 1999, s. 128. 
Ross ve Shulz (1999, s.128) ise geleneksel sınıf ortamlarının dişında özellikle çevrimiçi derslerde kullanılabilecek Web uygulamalarını ve etkinlikleri Gregorc öğrenme stillerine göre belirlemişlerdir. Bu uygulamalar Tablo 2'de sıralanmıştır.

\section{Gregorc Öğrenme Stillerine Sahip Öğrencilerin Kullanabilecekleri Stratejiler ve Taktikler}

Yukarıdaki özelliklerin ve öğretmenlerin öğrencilerinin stillerini dikkate alarak eğitim ortamlarını nasıl düzenleyebileceklerine dair önerilerin yanında Gregorc öğrencilerin kendi stillerine göre kullanabilecekleri öğrenme stratejileri ve taktikleri önermiştir. Güven (2004, s. 67-68) bu strateji ve taktikleri şöyle siralamaktadır:

Somut-Ardışık öğrenme stiline sahip bireyler denetim listeleri, ana çizgileri çıkarma, planlar, kavram haritaları, sınıflandırma, anahtar düşünceleri analiz etme, örnekler üretme, zamanı ve gücünü değerlendirme ve gözden geçirme stratejilerini kullanabilir. Soyut-Ardışık stildeki öğrenciler, not alma, ana çizgileri çıkarma, özetleme, çıkarsama yapma, sentez yapma, yeni ve eski bilgiyi karşılaştırma, zihinde tutmak için yineleme ve anahtar düşünceleri analiz etme stratejilerini kullanabilirler. Somut-Dağınık stildeki öğrenciler yeniden düzenleme, bağlantı kurma, araştırma, çizelgeler oluşturma, kavram haritaları oluşturma, nedenleri çıkarsama, etkileri değerlendirme, paragraflaştırma ve özetleme stratejilerini kullanabilirler. Soyut-Dağınık öğrenme stilindeki öğrenciler ise kısa okuma, ilişkisel düşünme, çıkarsama yapma, çözüm üretme, çizelgeleştirme, bütünü değerlendirme, yapılandırılmamış görevleri düzenleme, duyuşsal analiz, çok boyutlu analiz ve sembollerle gösterim stratejilerini işe koşabilirler.

\section{Gregorc Öğrenme Stillerine Göre Hazırlanmış Bir Uygulama Örneği}

Dersin Adı: Sosyal Bilgiler

Sinıf: 5

Ünitenin Adı: İnsanlar, Yerler ve Çevre

\section{Kazanımlar:}

- Haritalar üzerinde yaşadığı bölgenin yeryüzü şekillerini genel olarak kavrar.

- Yaşadığı bölgede görülen iklimin, insan faaliyetlerine etkisini, günlük yaşantısından örnekler vererek açıklar.

- Bölgesindeki doğal özellikler ile beșeri özelliklerin nüfus ve yerleşim üzerindeki etkilerini ilişkilendirir.

- Yaşadığı çevredeki afetlerin ve çevre sorunlarının oluşum nedenlerini sorgular.

- Doğal afetlerin toplum hayatı üzerine etkilerini örneklerle açılar.

Genel Açılkama: Öğrenciler, öğrenme stillerine uygun görevler üstlenerek yukarıdaki kazanımlara yönelik etkinlikler gerçekleştirebilir. 
Tablo 3. Gregorc Öğrenme Stili Özelliklerine Sahip Öğrencilerin "İnsanlar, Yerler ve Çevre" Ünitesinin Kazanımlarına Yönelik Gerçekleştirebileceği Görevler

\begin{tabular}{|c|c|c|c|}
\hline Somut Ardışık & Somut Dağınık & Soyut Ardışık & Soyut Dağınık \\
\hline $\begin{array}{l}\text {-Yaşadıkları bölgenin } \\
\text { yeryüzü şekillerini } \\
\text { gösteren harita hazırlama } \\
\text { - Haritalar üzerindeki } \\
\text { sembol, renk ve } \\
\text { kısaltmaların anlamlarını } \\
\text { açıklama } \\
\text { - Bölgedeki, zirai, sınai } \\
\text { ve turizm açısından } \\
\text { önemli ürün ve yerleri } \\
\text { harita üzerinde kısa } \\
\text { açıklamalarla gösterme } \\
\text { - Coğrafi özelliklerin } \\
\text { iklime etkisini örneklerle } \\
\text { gösterme (ölçeklendirme } \\
\text { kullanılmayacaktır) }\end{array}$ & $\begin{array}{l}\text { - Yaşadıkları bölgede } \\
\text { nüfus dağılımına etki } \\
\text { eden coğrafi faktörleri } \\
\text { açıklayan sunu hazırlama } \\
\text { - Bu bölgelere yapılacak } \\
\text { saha gezilerinde } \\
\text { arkadaşlarına rehberlik } \\
\text { etme } \\
\text { - Nüfus yoğunluğunun } \\
\text { azaltılmasına ve bölgenin } \\
\text { diğer yerlerine nasıl } \\
\text { yayılabileceğine ilişkin } \\
\text { çözüm önerileri getirme } \\
\text { - bölgenin potansiyel } \\
\text { doğal afetlerini } \\
\text { engelleyici çözüm } \\
\text { önerileri getirme }\end{array}$ & $\begin{array}{l}\text { - Sınıf dergisi hazırlama } \\
\text { - Bölgedeki çevre } \\
\text { sorunlarının nedenlerini } \\
\text { resim, fotoğraf, röportaj } \\
\text { vb. yollarla gösterme. } \\
\text { - Bölgedeki çevre } \\
\text { sorunlarına ilişkin } \\
\text { eleştirel köşe yazıları } \\
\text { yazma, } \\
\text { - Çevre sorunlarının nasıl } \\
\text { çözülebileceğine ilişkin } \\
\text { rapor hazırlama } \\
\text { - Bölgenin yaşadığı } \\
\text { doğal afetleri araştırma }\end{array}$ & $\begin{array}{l}\text { - İklim ve coğrafi } \\
\text { özelliklerin folklöre } \\
\text { (kıyafetler, şarkılar, } \\
\text { gelenekler vb.) etkisini } \\
\text { gösterme } \\
\text { - İklim ve coğrafi } \\
\text { özelliklerin bölgedeki } \\
\text { mesleklere / sanata } \\
\text { etkisini örneklerle } \\
\text { açıklama } \\
\text { - İklimin tarım } \\
\text { ürünlerine etkisini } \\
\text { gösteren video film } \\
\text { hazırlama } \\
\text { - Çevre kirliliği / doğal } \\
\text { afet sonuçlarını gösteren } \\
\text { bir kolaj hazırlama }\end{array}$ \\
\hline
\end{tabular}

Not: Yukarıdaki örnek uygulamanın ünite ve kazanımları MEB’nın 2017'de yayımladığı İlköğretim Programları, Sosyal Bilgiler taslak öğretim programından alınmıştır.

\section{Sonuç ve Öneriler}

Öğrenmenin ve öğretmenin doğasına odaklanan araştırmacılar farklı öğrenme stilleri belirlemişlerdir. Bunun sebebi de her araştırmacının öğrenme olgusunun farklı bir boyutuna ağırlık vermeleridir. Kimi araştırmacılar öğrenmenin bilişsel yönüne, kimileri duyuşsal yönüne diğerleri de devinimsel yönüne odaklanmışlardır. Bu çalışmada bilişsel bir öğrenme stili olan Gregorc'un Öğrenme Stili Sınıflandırması incelenmiştir. Kolb’un Öğrenme Stili Envanteri gibi iki temel boyutu ve dört alt boyutu, diğer bir deyişle, dört farklı öğrenme stili olan bu model en yaygın öğrenme stilleri modellerinden biridir. Gregorc'un bilişsel öğrenme stilleri, bilginin algılanması (somuttan

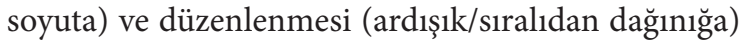
ilkesine dayanır. Gregorc'un Öğrenme Stilleri Ölçeği özellikle yetişkin bireylerin ya da üniversite öğrencilerinin öğrenme stillerinin belirlenmesinde sıklıkla kullanılan bir ölçektir. Ölçek bireyleri somut / soyut ve ardışık (sıralı) / dağınık olmak üzere iki doğrusal uzantıda uzanan bir çizgide değerlendirmekte ve bu doğruların uçlarına olan yakınlık ve uzaklıkları bireylerin o öğrenme stiline ne kadar güçlü ya da zayıf sahip olduğunu belirlemektedir (bakınız, Şekil 2).
Öğrenme stilleri kuramı farklı bireylerin bilgiyi alıp işlemede farklı öğrenme stillerini tercih ettikleri anlayışına dayanmaktadır. Bu sebeple öğretmenlerin s1nıflarında çok farklı öğrenme deneyimleri sağlayabilmeleri gerekmektedir. Bunun için de farklı öğrenme stillerinin ve bu öğrenme stillerine uygun etkinliklerin bilincinde olmalıdırlar. Öğrenmeyi etkileyen çok farklı etmenler olsa da öğrenme stilleri bu etmenlerin en önemlilerindendir. Öğretmenlerin de öğrencilerinin öğrenme stillerinin erken yaşlarda farkında olması ve öğrencilerin çoğuna hitap edecek bir denge kurarak zengin öğrenme-öğretme ortamları düzenlemeleri gerekmektedir. Ancak eğitim durumlarının öğrenme stilleri ile uyumunun yanında öğrencilerin zaman zaman kendilerini zorlayıcı etkinlikleri de yerine getirmelerini sağlamak onların zayıf bilişsel alanlarını geliştirmelerine katkı sağlayabilecektir. Öğretmenlerin bazen bilinçli olarak öğrencilerini bilişsel stilleri ile uyumlu olmayan etkinliklere yönlendirmesi onların akademik başarılarını artırmada, sürekli dinamik kılmada ve güdülemede faydalı olabilmektedir (Birchman ve Sadowski, 2007, s.19; Lemire, 1996, s.58; Williamson ve Watson, 2007, s.66). Aksi takdirde eğitim durumları hem öğrenciler hem 
de öğretmenler için bir süre sonra sıkıcı olabilmekte ve aynı türde etkinliklerle uğraşan öğrencilerde rehavete sebep olabilmektedir (Williamson ve Watson, 2007, s.66). Lemire (1996, s. 58) de genç öğrenenlerin yalnızca üçte birinin tek bir baskın öğrenme stiline sahip olduğunu, diğer üçte birlik kesimin iki baskın öğrenme stiline sahip olduğunu ve geriye kalan üçte birlik kesimin ise belirgin bir öğrenme stiline sahip olmadığını ifade etmektedir. Bu sebeple öğretmenlerin hem sinıfta farklı öğrenme stillerinin hepsine hitap edebilecek zengin öğretme stratejisi, yöntem ve tekniklerine sahip olması, hem de hangi etkinliklerin hangi öğrenme stilindeki öğrencilerle en iyi öğrenmeyi sağlayabileceğini bilmeleri önem kazanmaktadır.

\section{Kaynakça}

Birchman, J. A. \& Sadowski, M. A. (2009). Strategies for bridging learning styles. Engineering Design Graphics Journal, 71(1).

Cassidy, S. (2004). Learning styles: An overview of theories, models, and measures. Educational Psycho$\log y, 24(4), 419-444$.

Davidson, G. V., Savenye, W. C., \& Orr, K. B. (1992). How do learning styles relate to performance in a computer applications course? Journal of Research on Computing in Education, 24(3), 348-358.

Ekici, G. (2002). Gregorc öğrenme stili ölçeği. Eğitim ve Bilim, 27(123), 42-47.

Ekici, G. (2003). Uzaktan eğitim ortamlarının seçiminde öğrencilerin öğrenme stillerinin önemi. Hacettepe Üniversitesi Eğitim Fakültesi Dergisi, 24 (24), 48-55.

Ekici, G. (2013). Gregorc ve Kolb öğrenme stilleri modellerine göre öğretmen adaylarının öğrenme stillerinin cinsiyet ve genel akademik başarı açısından incelenmesi. Eğitim ve Bilim, 38(167), 211-225.

Güven, M. (2004). Öğrenme stilleri ile öğrenme stratejileri arasındaki ilişki. Eskişehir: Anadolu Üniversitesi Eğitim Fakültesi Yayınları.

Hawk, F. T. \& Shah, A. J. (2007). Using learning style instruments to enhance student learning. Decision Sciences Journal of Innovative Education, 5(1), 1-19.
Joniak, A.J. \& Isaksen, S. G. (1988). The Gregorc style delineator: Internal consistency and its relationship to Kirston's adaptive-innovative distinction. Educational and Psychological Measurement, 48, 1043-1049.

Kolb, D. A. (1984). Experiential learning: Experience as the source of learning and development. Englewood Cliffs, NJ: Prentice- Hall.

Kurt, H., Ekici, G. \& Aktaş, M. (2014). Biyoloji öğretmen adaylarının öğrenme stilleriyle kişilik tiplerinin ilişkisi. Eğitim ve Öğretim Araştırmaları Dergisi, 3(1), 50-59.

Lemire, D. (1996). Using learning styles in education: Research and problems. Journal of Accelerative Learning and Teaching, 21, 43-58.

Miller, L. M. (2005). Using learning styles to evaluate computer-based instruction. Computers in Human Behavior, 21, 287-306.

Moore, B. R. (1990). The relationship between curriculum and learner: Music composition and learning style. Journal of Research in Music Education, 38(1), 24-38.

Ross, J. L. \& Shulz, R. A. (1999). Using the World Wide Web to accommodate diverse learning styles. College Teaching, 4 (4), 123-129.

Ross, J. L. Drysdale, M. T., \& Schulz, R. A. (2001a). Cognitive learning styles and academic performance in two postsecondary computer application Courses. Journal of Research on Computing in Education, 3 (4), 400-412.

Ross, J. L. Drysdale, M. T. \& Schulz, R. A. (2001b). Cognitive learning styles and academic performance in 19 first-year university courses: Successful students versus students at risk. Journal of Education for Students Placed at Risk, 6 (3), 271-289.

Terry, M. (2002). Translating learning style theory into developmental education practice: An article based on Gregorc's cognitive learning styles. Journal of College Reading and Learning, 32(2), 154-176.

Williamson, M. F. \& Watson, R. L. (2007). Learning styles research: Understanding how teaching should be impacted by the way learners learn part III: Understanding how learners' personality styles impact learning. Christian Education Journal, 4 (1), 62. 